\title{
Technological Pedagogical and Content Knowledge (TPACK) of Special Education Teachers in Science Instruction for Students with Special Needs
}

\author{
Leni Ambar Cahyani ${ }^{(1, *)}$, Nur Azizah², David Evans ${ }^{3}$ \\ ${ }^{1,2}$ Universitas Negeri Yogyakarta \\ ${ }^{3}$ Universitas of Sydney
}

\section{Received: January 26, 2021 \\ Revised: March 01, 2021 \\ Accepted: March 03, 2021}

\begin{abstract}
Integration of technology in science instruction in special education context can be implemented within the technological, pedagogical, and content knowledge (TPACK) framework. Therefore, special education teachers are expected to have a good level of TPACK. This study aimed to explore the level of teachers TPACK in science instruction for students with special needs. This research also was addressed to compare the TPACK level of teachers based on their gender. This research used a quantitative approach with survey method. The respondents of this study were special education teachers $(\mathrm{N}=44)$. The data collection method was through a survey using the TPACK survey instrument. The validation result used the Pearson Correlation showed value per statement ranging from $0.504-0.904$. Reliability showed in the Cronbach's coefficient Alpha for internal consistency value of 0.856 (high). The data analysis technique used was the descriptive statistical analysis technique and the independent sample $t$ test. The results showed that each TPACK domain for both gender was in a very good and good category. Female teachers were seen to be superior in most of the domains. This research also found that there was no difference of the TPACK level between male and female teacher. The issue of gender equality that has begun to be implemented in Indonesia and the ease of access to technological knowledge can be the reason for the loss of technological mastery differences. In conclusion, there was no difference of the TPACK level in science instruction between male and female special education teacher.
\end{abstract}

Keywords: TPACK, science instruction, special education teacher

(*) Corresponding Author: $\quad$ leniambar.2019@student.uny.ac.id

How to Cite: Cahyani, L.A., Azizah, N., \& Evans, D. (2021). Technological pedagogical and content knowledge (TPACK) of special education teachers in science instruction for students with special needs. Formatif: Jurnal Ilmiah Pendidikan MIPA, 11 (1): 103-112. http://dx.doi.org/10.30998/formatif.v11i1.8580

\section{INTRODUCTION}

Student with special needs are children who experience difficulties in learning as well as those whose performance is so advanced that modifications in curriculum and instruction are necessary to help them fulfill their potential (Heward, Alber-Morgan, \& Konrad, 2016). The number of students with special needs in Indonesia keeps increasing year by year. In 2018, The Indonesia Ministry of Education and Culture reported that they were 133.826 students with special needs in Indonesia (Ministry of Education and Culture, 2018). This number is higher than the previous year amounted 128.510 students (Ministry of Education and Culture, 2017).

Science is an important subject in the general education curriculum. Science education not only makes students' progress academically but also socially by enhancing their interpretation and exploration of their environment (Ozguc \& Cavkaytar, 2015). For 
students with special needs, the science curriculum provided is usually limited according to students' abilities (Karvonen et al., 2011) and the methods used in science instruction are also different (Browder et al., 2014). The difference in methods in delivering science material is carried out considering that students with special needs need adjustments or modifications in learning. On the other hand, teaching science to students with special needs is a challenge, considering their learning characteristics.

Teachers and researchers have tried several ways to help students with special needs in science instruction, including the use of technology. For typical students, computer-based learning has a significant effect on student independence in science learning (Aditama \& Sadhu, 2019). This also applies to students with special needs. For students with special needs, utilizing technology including computers to deliver learning materials through interactive images, videos, animations, and games, makes computers an independent support for students and teachers (Hew \& Cheung, 2010; Rutten, van Joolingen, \& van der Veen, 2012). This is because technology integrates color, sound and computer images which can improve students' understanding (Chai, Vail \& Ayres, 2014).

Technology can be integrated in learning through the Technological Pedagogical and Content Knowledge (TPACK) framework. TPACK is a combination of three knowledge domains, namely content, pedagogy, and technology in teaching. The TPACK framework is built on the PCK (pedagogical and content knowledge) description explained by Shulman (1986) and how teachers' understanding of technology in education to produce effective teaching with technology (Koehler, Mishra, \& Cain 2013; Schmidt et al., 2009). Equally important for this model is the interaction between and among these domains of knowledge, represented as PCK, TCK (technology and content knowledge), TPK (technology pedagogical knowledge), and TPACK. The following is an explanation of each component (Koehler, Mishra, \& Cain, 2013; Schmidt et al., 2009).

Table 1. TPACK Domain

\begin{tabular}{l}
\hline TPACK Domain \\
\hline Content Knowledge \\
(CK) \\
Pedagogical Knowledge \\
(PK) \\
Technological Knowledge \\
(TK)
\end{tabular}

Pedagogical and Content Knowledge (PCK) Definition Teachers' knowledge of the subject matter to be studied or taught. Teachers' in-depth knowledge of the processes and practices or methods of teaching and learning

Knowledge of various technologies, ranging from low technology and digital technologies such as the internet, digital video, and software programs.

Content knowledge related to the teaching process. This domain combines content and pedagogy to develop better teaching practices in the content area.

Technological and Content Technology refers to knowledge of how technology can Knowledge (TCK) create new representations for certain content.

Technological Pedagogical Knowledge of how various technologies can be used in Knowledge (TPK) teaching

Technological Pedagogical and Content Knowledge

Knowledge needed by teachers to integrate technology (TPACK) into their teaching in any content area they teach.

In Indonesia, teachers have obligation to increase their competencies, including in science, technology, and art skills (Law Number 14 of 2005 on Teachers and Lecturers). Furthermore, the benefits of using technology in the learning process of students with special needs (Chai, Vail \& Ayres, 2014; Hew \& Cheung, 2010; Rutten, van Joolingen \& 
van der Veen, 2012) make teachers have to master the use of technology. Therefore, teachers need to master technological skills to increase their competencies and create a good instruction for the students. In Indonesia, research on TPACK has begun to be widely carried out. In the field of natural science, Suryawati, Linggasari, and Arnentis (2017) studied the TPACK of biology prospective teachers. However, most of these studies are not in the special education context. In fact, research on TPACK in the field of special education has been carried out in many countries (Demirok \& Baglama, 2018; Huang, Chen \& Jang, 2020; Lyublinskaya \& Tournaki, 2014). For this reason, it is also needed to measure the level of TPACK of special education teachers in Indonesia.

There are factors that influence the implementation of the TPACK framework, including teachers. Teachers' TPACK is complex since it is influenced by many factors such as differences in characteristics that affect the learning process to be carried out (Astuti et al., 2019). Teacher personality factors can also influence teaching methods, including gender, age, teaching experience, character, and beliefs (Cruickshank et al., 2012). Several studies have shown that gender is a factor affecting teacher TPACK and there is a significant difference in TPACK against teacher gender, in which men have a higher TPACK than women (Lin et al., 2013; Liu, Zhang, \& Wang, 2015). Even so, Astuti et al., (2019) found that there was no difference in the TPACK level between male and female teachers. The different results on the influence of gender on TPACK needed to be studied more deeply especially in special education context. The dominance of the TPACK ability of male teachers indicated a critical situation for special education since most of the teachers in special education are women (Ministry of Education and Culture, 2018). If they have low TPACK level, it is possible that teachers' technological competence in special education is also low.

TPACK is influenced by many factors, in which gender is one factor that remains unclear. Some studies said that women's TPACK is lower which can affect their competence in teaching and integrating technology into their instruction. Whereas the field of special education in Indonesia is dominated by female teachers. The data from the Ministry of Education and Culture from 2016 to 2018 showed that the number of female special education teachers was higher than male teachers. In 2016, there were 17,355 female teachers and 7,302 male teachers. Meanwhile, in 2017 there were 17,630 female teachers and 6,704 male teachers. The latest data in 2018 reported that there were 19,259 female teachers and only 7,620 male teachers. Based on data from year over year, it can be seen that nationally the proportion of female teachers is always growing. Whereas in Yogyakarta in 2017, there were 865 female teachers and 358 male teachers (Ministry of Education and Culture, 2017).

The gender issue might be the reason for difference in technological knowledge between male and female. In Asia, including in Indonesian culture, men still hold the leading role in many aspects of life. This male-dominated social structure is called patriarchy (Dewi, 2019). Recently, technology is always associated with male, although technology is very useful and helpful for both males and females living in the era of globalization (Suwana \& Lily, 2017). Gender equality in technology is hard to be accomplish since a gender mainstreaming policy has still not been properly implemented in Indonesia (Wakhidah, 2012). For example, a study done by Latif et al., (2019) found that there is a significant influence between teacher gender and ICT literacy in Indonesia. This means, in general, gender still has a significant influence on mastery of ICT in Indonesia.

Observing the increasing number of children with special needs in Indonesia and the importance of science education for students with special needs as well as opportunities to use technology within the TPACK framework, it is necessary to conduct preliminary research. Given that the number of female teachers in the context of special 
education is more than male teachers and patriarchal culture in Indonesia, it is necessary to conduct research to find out for sure. Therefore, this study aimed to determine the TPACK level of special education teachers in science instruction. This study also aimed to compare the TPACK level of special education teachers in science instruction based on their gender.

\section{METHODS}

This study used a quantitative approach while the type of research was a survey research. Therefore, the data collection was done by using a survey method. This survey was conducted within three weeks from December $9^{\text {th }}$ until $30^{\text {th }} 2020$. The population of this study is special education teacher in Yogyakarta City. The respondents of this study were special education teachers both in inclusive schools and in special schools with total $n=44$. The sample of this study were selected using the convenience sampling technique as it is readily available and simple to implement. The characteristics of respondents dominated by teachers of student with special needs who have been teaching for at least 1 year and have a bachelor's degree in special education. The demographic data of the research participant is presented in the table 2 .

Table 2. Demographic Data of Research Participants

\begin{tabular}{clll}
\hline Construct & Category & Frequency & Percentage \\
\hline Gender & Female & 27 & $61.4 \%$ \\
& Male & 17 & $38.6 \%$ \\
Age & $21-25$ & 27 & $61.4 \%$ \\
& $26-30$ & 11 & $25 \%$ \\
& $31-35$ & 3 & $6.8 \%$ \\
Seniority & $36-40$ & - & - \\
& $>40$ & 3 & $6.8 \%$ \\
& $1-2$ years & 21 & $47.7 \%$ \\
& 3-4 years & 15 & $34.1 \%$ \\
& 5-6 years & 3 & $6.8 \%$ \\
& $>6$ years & 5 & $11.4 \%$ \\
\hline
\end{tabular}

The data were collected through the Technological, Pedagogical, and Content Knowledge Questionnaire which was developed and validated by Desstya (2018). The questionnaire was sent to the participants via Google Form. It consists of 29 items about TPACK on a 4-point Likert scale. Examples of instrument items include "I can make a PowerPoint Presentation to show / explain the concept of science material" and "I understand how to use ICT media to develop lesson plans". TPACK model 29 statements in the questionnaire are divided into statements about TK (6 items), PK (4 items), CK (4 items), PCK (5 items), TCK (4 items), TPK (3 items) and TPACK (3 items). Every item in the questionnaire is four Likert scale. Likert scale question comprised four points ranking following: "strongly agree" (4 points), "agree" (3 points), "disagree" ( 2 points), "strongly disagree" (1 point). The instrument validation result done by Desstya (2018) used the Pearson Correlation showed value per statement ranging from $0.504-0.904$. Reliability showed in the Cronbach's coefficient Alpha for internal consistency value of 0.856 (high).

Data analysis was carried out with descriptive statistics and test to compare the level of TPACK of the special education teachers. Descriptive analysis was carried out to 
see the TPACK level of teachers in each domain by representing and interpreting data categories using Arikunto's (2011) categorization. First, the data is processed from the raw scores to the fine scores with the following formula:

$$
\begin{array}{ll}
\mathrm{P}=\frac{f}{N} x & 100 \\
\mathrm{P} & =\text { value } \\
\mathrm{F} & =\text { obtained value } \\
\mathrm{N} & =\text { maximum value }
\end{array}
$$

The fine scores obtained were then entered into the categorization table. Researchers used categorization table from Arikunto (2011). This categorization is divided into five categories with the TPACK mastery criteria presented as follows:

Table 3. Teachers TPACK Level Category

\begin{tabular}{ll}
\hline Value & Category \\
\hline $84-100$ & Very good \\
$68-83$ & Good \\
$52-67$ & Enough \\
$36-51$ & Low \\
$\leq 35$ & Very low \\
\hline
\end{tabular}

\section{RESULTS \& DISCUSSION}

\section{Results}

This research was conducted through a survey method. The researchers used the google form platform to collect data. After the online instrument was created, a link was sent to the respondents. After collecting the survey data from 44 respondents, the researcher obtained information about the level of TPACK for special education teachers in science instruction for students with special needs. First, descriptive analysis was carried out to determine the level of TPACK at the teacher level which is divided into seven TPACK domains which can be seen in the following table.

Table 4. Teachers' TPACK Level

\begin{tabular}{ccccccc}
\hline $\begin{array}{c}\text { TPACK } \\
\text { Domain }\end{array}$ & & Male & & & Female \\
\hline & Mean & SD & Category & Mean & SD & Category \\
\hline TK & 89.95 & 12.85 & Very good & 90.28 & 8.95 & Very good \\
PK & 84.87 & 17.29 & Very good & 84.92 & 13.48 & Very good \\
CK & 75.00 & 15.78 & Good & 75.23 & 10.89 & Good \\
PCK & 73.90 & 14.70 & Good & 76.16 & 9.34 & Good \\
TCK & 84.56 & 16.26 & Very good & 84.26 & 10.01 & Very good \\
TPK & 84.80 & 15.93 & Very good & 83.64 & 10.96 & Very good \\
TPACK & 75.00 & 16.40 & Good & 76.54 & 9.82 & Good \\
\hline
\end{tabular}

In general, it can be seen that each domain in both genders is included in the very good and good category. In addition, each domain of the two groups of participants also fell into the same category. Female teachers are seen to be superior in the TK, PK, CK, 
PCK, and TPACK domains. Meanwhile, male teachers were only slightly superior in the TCK and TPK domains.

TK is seen as the domain with the highest score in both male and female teachers (89.95 and 90.29 respectively) which mean teachers seem to have a high level of technological knowledge. The difference in TK scores in the two groups of participants was also relatively small. Furthermore, PK is seen to be the second ranked domain in both groups. For male teachers, PCK was the domain with the lowest score (73.90). Whereas for female teachers, the domain with the lowest score was CK (75.23). Based on the table, it can be seen that the domains related to content knowledge tend to have a lower mean value compared to other domains. CK indicates teachers' knowledge of the science subject matter to be studied or taught. Even though it is in the good category, this needs to be known. That is, teachers tend to think that they have low content knowledge in science subjects.

The next analysis was carried out to determine whether there is a difference in the level TPACK of teachers based on gender. The TPACK level were compared with an independent sample t-test. The results of TPACK level analysis based on gender are presented in the following table.

Table 5. Comparison of Teachers' TPACK based on Gender

\begin{tabular}{llllll}
\hline Gender & $\mathrm{n}$ & mean & SD & $\mathrm{t}$ & $\mathrm{p}$ \\
\hline Female & 27 & 81.44 & 7.37 & 0.123 & 0.90 \\
Male & 17 & 81.03 & 12.58 & & \\
\hline P $<0.05$ & & & &
\end{tabular}

$\mathrm{P}<0.05$

Since the data is normally distributed, the t-test which is a statistic parametric was applied in order to determine whether TPACK levels of special education teachers significantly differ based on their gender. Table 5. demonstrates t-test results on gender and TPACK levels of special education teachers. As it can be seen, TPACK levels of special education teachers do not show significant difference based on their gender. The mean scores between the two groups, shows there are no significant different. Based on the results of calculations that have been done, the $t$ value obtained was amounted 0.123 .

The $t$ value in the $t$ table with a significance level of 0.05 indicated the value of $t$ $=2,085$. Furthermore, the $\mathrm{t}$ value obtained was compared to the critical $\mathrm{t}$ value in the $\mathrm{t}$ table. When compared, it can be seen that the $t$ value (0.123) is less than the critical $t$ value in the $\mathrm{t}$ table (2.085). Therefore, $\mathrm{H}_{0}$ is accepted. Hypothesis testing using the $\mathrm{p}$ value also shows the same results. The $\mathrm{p}$ value obtained was 0.90 . Using a comparison of $\mathrm{p}$ value 0.05 , it can be seen that $0.90>0.05$, so that $\mathrm{H}_{0}$ is accepted. With $\mathrm{H}_{0}$ accepted in each domain, it can be concluded that there is no difference in the TPACK level of the teachers based on their gender. In other words, there was no difference of the TPACK level in science instruction between male and female special education teacher.

\section{Discussion}

This study aimed to explore the TPACK level of special education teachers in science instruction for students with special needs and to compare the level of TPACK of teachers based on their gender. This study found that each domain for both genders is included in a very good category and good category. The TPACK domain for both males and females also showed in good category. These findings are in line with the study done by Demirok and Baglama (2018) which found that TPACK levels of special education teachers is high. Other studies also showed the same findings (Huang, Chen, \& Jang (2020; Mai \& Hamzah, 2016). These similar research results support the finding of the 
present study. This result was obtained as most of the respondents are young teachers, who make them more familiar with the use and integration of technology into their instruction. On the other hand, teachers with elder age may have less technological knowledge. This statement is reinforced by the opinion of Liang et al., (2013) who reported that teachers with older age tend to have less technological knowledge and ICT integration so that they can have moderate barriers to implementing technology in the learning environment.

Comparing both genders, female teachers seemed more advanced in most of the domain (TK, PK, CK, PCK, and TPACK). Whereas male teachers only slightly superior in TCK and TPK domain. This means that female teachers in special education showed better competence in TPACK compared to male teachers. The previous findings (Lin et al., 2013; Liu, Zhang, \& Wang, 2015) stated that men are more likely to excel in technological abilities. However, the results of this study showed that female teacher are more superior in most domain of TPACK.

TK was the domain with the highest mean score in both male and female teachers. The same finding also found by Mai and Hamzah (2016) which found the TK score was higher than the other TPACK subscales. The abundance of information that can be accessed online about how to integrate technology in learning may improve teacher's knowledge. Nowadays, web-based professional development programs are increasingly popular so that teachers can learn independently to increase the knowledge of technology needed in their instruction they might need (Liang et al., 2013). Therefore, it is possible that the level of technology mastery has increased.

This study also found that for male teachers, the domain with the lowest score was PCK. Meanwhile, CK was the lowest mean value for female teachers compared to other domains. Therefore, it can be concluded that the domains related to content knowledge tend to have lower mean value compared to other domains. This means teachers feel that they have lower abilities in mastering learning material in science subjects. However, this finding contradicted with the previous studies such as a study done by Peng and Daud (2016) which found that special schoolteachers showed high CK level. This means that there is still uncertainty regarding the level of CK in special education teachers especially in science instruction. Therefore, further research needs to be done.

The comparative t-test in the study showed that there was no difference in the TPACK level between teachers based on their gender. This results in accordance with some research that showed no significant gender influence on TPACK (Astuti et al., 2019; Demirok \& Baglama, 2018; Hsu \& Chen, 2018; Mai \& Hamzah, 2016). These findings, however, contradict with the previous opinion by Latif et al., (2019) which stated that male teachers know more and do better work using ICT devices than female. More specifically some research found that men have a higher TPACK than women (Lin et al., 2013; Liu, Zhang, \& Wang, 2015).

The issue of gender equality that has begun to be implemented in Indonesia could be the reason for the loss of technological differences between men and women in technological mastery. In 2012, Wakhidah stated that gender equality in technology is hard to be accomplish because a gender mainstreaming policy has still not been properly implemented. However, along with the time, the issue of gender equality is increasingly becoming a concern and being implemented. Women's groups or the community have become a target for digital literacy programs for the country. For example, Suwana and Lily (2017) did an interview to Indonesia's Deputy Minister of Women's Empowerment and Child Protection for Gender Mainstreaming in the Economy, Sulikanti Agusni, who argued that the internet gives chances for mothers or housewives to become entrepreneurs. Therefore, they can produce additional income for households. With the 
decreasing issue of gender differences in technology, the level of mastery of technology for male and female teachers is no longer different.

Another reason that can contribute to the loss of differences in technology mastery between men and women is the ease of access to technological knowledge. For example, Liang et al., (2013) stated that web-based professional development programs are increasingly popular which made teachers can learn independently to increase the knowledge of technology they might need in their instruction. They can easily access to increase their competencies via online. This is, of course, make it easier for men and women to acquire technological knowledge. As a consequence, this can also reduce the gap in technology mastery between men and women.

\section{CONCLUSION}

In conclusion, this study found that each domain for both genders is included in a very good category and good category. Female teachers were seen to be superior in most of the domains. The TK was the domain with the highest mean value in both male and female teachers. It was because most of the respondents are young teachers who make them more familiar with technology. The domains related to content knowledge tend to have lower mean values. The comparative t-test in the study showed that there was no difference in the TPACK level between teachers based on their gender. This means that teachers' TPACK level is not differentiated by their gender. The issue of gender equality that has begun to be implemented in Indonesia and the ease of access to technological knowledge can be the reasons for the loss of differences in technological mastery abilities between men and women. This research still has limitations due to the relatively small number of respondents in survey research. Therefore, further research should be done with more data and heterogeneous samples to increase the generality of study result. Thus, decisions can be made regarding the use of the TPACK framework in science learning for students with special needs.

\section{ACKNOWLEDGEMENT}

The authors would like to thank the lecturers from Special Education Department who have helped in conducting the study and also thank to all special education teachers who have volunteered to participate in the study.

\section{REFERENCES}

Aditama, B. A. \& Sadhu, S. (2019). The effect of implementing media computer-based instruction (simulation model) towards student's autonomy in science learning. Formatif: Jurnal Ilmiah Pendidikan MIPA, 9 (4), 291-304. http://dx.doi.org/10.30998/formatif.v9i4.3522

Arikunto, S. (2011). Dasar - Dasar Evaluasi. Jakarta: Bumi Aksara.

Astuti, F. E. C., Paidi, Subali, B., Hapsari, N., Pradana, S. P., \& Anthony, M. K. (2019). TPACK mastery of biology teachers: a study based on teacher gender. Journal of Physics: Conf. Series 1397 012050. https://doi.org/10.1088/1742$6596 / 1397 / 1 / 012050$ 
Browder, D. M., Wood, L., Thompson, J., \& Ribuffo, C. (2014). Evidence-based practices for students with severe disabilities (Document No. IC-3). Retrieved from http://ceedar.education. ufl.edu/tools/innovation-configurations/

Chai Z., Vail, C. O., \& Ayres, K. M. (2014). Using iPad applications to promote early literacy development in young children with disabilities. The Journal of Special Education, 48(4), 268-278. https://doi.org/10.1177/0022466913517554

Cruickshank, D. R., Jenkins, D. B., \& Metcalf, K. K. (2012). The Act of Teaching: Sixth Edition. New York: Mc Graw Hill.

Demirok, M. S. \& Baglama, B. (2018). Examining technological and pedagogical content knowledge of special education teachers based on various variables. TEM Journal, 7(3), 507-512. https://dx.doi.org/10.18421/TEM73-06

Desstya, A. (2018). Validitas reliabilitas instrument technologycal pedagogical content knowledge (TPACK) guru sekolah dasar muatan pelajaran ipa. Journal Basic of Education, 3 (1), 126- 139. http://doi.org/10.24269/ajbe.v3i1.1338

Dewi, D. M. (2019). The representation of patriarchy in Indonesian children folk tales from Sumatra island. Lingua Cultura, 13(3), 167-172. https://doi.org/10.21512/lc.v13i3.5646

Hew, K. F., \& Cheung, W. S. (2010). Use of three-dimensional (3D) immersive virtual worlds in K-12 and higher education settings: A review of the research. British Journal of Educational Technology, 41(1), 33-55. https://doi.org/10.1111/j.14678535.2008.00900.x

Heward, W. L., Alber-Morgan, S. R., \& Konrad, M. (2016). Exceptional Children: An Introduction to Special Education. New York: Pearson.

Hsu, L. \& Chen, Y. (2018). Teachers' Knowledge and Competence in the Digital Age: Descriptive Research within the TPACK Framework. International Journal of Information and Education Technology, 8(6), 455-458. http://doi.org/10.18178/ijiet.2018.8.6.1081

Huang, K, Chen, Y. \& Jang, S. (2020). TPACK in special education schools for svi: a comparative study between taiwanese and chinese in-service teachers. International Journal or Disability, Development and Education. Advance online publication. https://doi.org/10.1080/1034912X.2020.1717450

Karvonen, M., Wakeman, S. Y., Browder, D. M., Rogers, M. A. S., \& Flowers, C. (2011). Academic curriculum for students with significant cognitive disabilities: Special education teacher perspectives a decade after IDEA 1997. Charlotte, NC: University of North Carolina at Charlotte, National Alternate Assessment Center. Retrieved from https://eric.ed.gov/?id=ED521407

Koehler, M. J., Mishra, P., \& Cain, W. (2013). What is technological pedagogical content knowledge (TPACK)? Journal of Education, 193(3), 13-19. https://doi.org/10.1177/002205741319300303

Latif, M. A., Abdullah, A. G., Hakim, D. L., Widiaty, I., Islami, A. R., Zakaria, D., Arasid, W., \& Anggraeni, A. (2019). ICT literacy level analysis of elementary school teachers. Journal of Physics: Conference Series. 1375012095. https://doi.org/10.1088/1742-6596/1375/1/012095

Law of the Republic of Indonesia Number 14 of the year 2005 concerning Teachers and Lecturer. Jakarta: Depdiknas.

Liang, J. C., Chai, C. S., Koh, J., Yang, C., \& Tsai, C. C. (2013). Surveying in-service preschool teachers' technological pedagogical content knowledge. Australasian Journal of Educational Technology, 29(4), 581-594. https://doi.org/10.14742/ajet.299 
Lin, T. C., Tsai, C. C., Chai, C. S., \& Lee, M.H. (2013). Identifying science teachers' perceptions of technological pedagogical and content knowledge (TPACK). Journal Science Education Technology, 22(3), 325-336. https://doi.org/10.1007/s10956-012-9396-6

Liu, Q., Zhang, S., \& Wang, Q. (2015). Surveying chinese in-service k12 teachers' technology, pedagogy, and content knowledge. Journal of Educational Computing Research, 53(1), 55-74. https://doi.org/10.1177/0735633115585929

Lyublinskaya, I. \& Tournaki, N. (2014). Preparing special education teachers for teaching mathematics and science with technology by integrating the TPACK framework into the curriculum: a study of teachers' perceptions. Journal International of Technology and Teacher Education, 22(4), 449- 470. Retrieved from https://www.learntechlib.org/p/111837.

Mai, M. Y. \& Hamzah, M. (2016). Primary Science Teachers' Perceptions of Technological Pedagogical and Content Knowledge (TPACK) In Malaysia. European Journal of Social Sciences Education and Research, 3(2), 167-179. http://dx.doi.org/10.26417/ejser.v6i2.p167-179

Ministry of Education and Culture. (2017). Statistik Sekolah Luar Biasa (SLB) 2017/ 2018. Jakarta: Sekretaris Jenderal Pusat Data dan Statistik Pendidikan dan Kebudayaan.

Ministry of Education and Culture. (2018). Statistik Pendidikan Luar Biasa (PLB) 2018/ 2019. Jakarta: Sekretaris Jenderal Pusat Data dan Statistik Pendidikan dan Kebudayaan.

Ozguc, C. S. \& Cavkaytar, A. (2015). Science Education for Students with Intellectual Disability: A Case Study. Journal of Baltic Science Education, 14(6), 804-821. Retrieved from http://journals.indexcopernicus.com/abstract.php?icid=1192288

Peng, C. A. \& Daud, S. M. (2016). Relationship between special education (hearing impairment) teachers' technological pedagogical content knowledge (TPACK) and their attitudes toward ICT integration. Proceeding of International Conference on Special Education in Southeast Asia Region 6th Series, 1-13. Bangi: Universiti Kebangsaan Malaysia.

Rutten, N. P. G., van Joolingen, W., \& van der Veen, J. T. (2012). The learning effects of computer simulations in science education. Computers \& education, 58(1), 136153. https://doi.org/10.1016/j.compedu.2011.07.017

Schmidt, D. A., Baran, E., Thompson, A. D., Mishra, P., Koehler, M. J., \& Shin, T. S. (2009). Technological pedagogical content knowledge (TPACK): The development and validation of an assessment instrument for preservice teachers. Journal of Research on Technology in Education, 42 (2), 123-149. https://doi.org/10.1080/15391523.2009.10782544

Shulman, L. (1986). Those who understand: Knowledge growth in teaching. Educational Researcher, 15(2): 4-14. https://doi.org/10.3102/0013189X015002004

Suryawati, E., Linggasari, M. N., \& Arnentis. (2017). Technological Pedagogical and Content Knowledge of biology prospective teachers. Biosaintifika Journal of Biology \& Biology Education, 9(3), 498-505. https://doi.org/10.15294/biosaintifika.v9i3.11270

Suwana, F. \& Lily. (2017). Empowering Indonesian women through building digital media literacy. Kasetsart Journal of Social Sciences, 38 (3), 212-217. https://doi.org/10.1016/j.kjss.2016.10.004

Wakhidah, N. (2009). Perempuan dalam perkembangan ilmu pengetahuan dan teknologi. EGALITA: Jurnal Kesetaraan dan Keadilan Gender, 4(2), 147- 158. https://doi.org/10.18860/egalita.v0i0.1912 